\title{
JEJAK KESULTANAN PALEMBANG DARUSSALAM DI KABUPATEN BANYUASIN
}

\author{
Oleh: Jeki Sepriady ${ }^{*}$, Muhamad Idris** \\ *Mahasiswa Program Studi Pendidikan Sejarah, FKIP Universitas PGRI Palembang \\ ${ }^{*}$ Dosen Program Studi Pendidikan Sejarah, FKIP Universitas PGRI Palembang
}

\begin{abstract}
ABSTRAK
Orang asli Banyuasin adalah suku Melayu kelompok manusia yang pertama menetap di Banyuasin. Mereka selalu bermusyawarah dan mufakat setiap ada sesuatu yang penting. Falsafah hidupnya beragam Islam dan menggunakan bahasa Melayu. Semuanya ini ada dalam perkembangan sejarah kehidupan masyarakat Banyuasin. Rumusan masalah: bagaimanakah jejak Kesultanan Palembang Darussalam di kabupaten Banyuasin?. Tujuan penelitian: untuk mengetahui jejak Kesultanan Palembang Darussalam di kabupaten Banyuasin. Metode dalam penelitian ini adalah metode deskriptif kualitatif. Teknik pengumpulan data melalui dokumentasi, observasi, dan wawancara. Teknik analisis data yaitu reduksi data, penyajian data dan penerikan kesimpulan. Bayuasin sebagai wilayah kekuasaan kesultanan Palembang Darussalam termasuk kategori daerah sikep. Sama dengan sistem pemerintahan marga daerah di daerah Uluan, wilayah Banyuasun zaman marga kesultanan Palembang Darussalam tidak mempunyai pemerintahan sendiri, tetapi diperintah langsung oleh jenang atau pegawai yang ditunjuk raja Palembang.
\end{abstract}

Kata Kunci: Kesultanan Palembang Darussalam, Kabupaten Banyuasin

\section{A. PENDAHULUAN}

Wilayah Sumatera Selatan dikenal juga sebagai daerah Batanghari Sembilan karena di wilayah ini terdapat sembilan sungai besar yang dapat dilayari sampai ke hulu, yaitu sungai Musi, Ogan, Komering, Lematang, Kelingi, Rawas, Batanghari Leko, Banyuasin dan Lalan. Sungai-sungai besar ini merupakan urat nadi kehidupan masyarakat sejak masa lampau berdasarkan bukti-bukti arkeologis yang tersebar di daerah aliran sungai (Rangkuti, 2007:1).

Kabupaten Banyuasin adalah salah satu kabupaten di provinsi Sumatera Selatan. Kabupaten ini merupakan pemekaran dari kabupaten Musi Banyuasin yang terbentuk berdasarkan UU No. 6 Tahun 2002. Kabupaten Banyuasin dibentuk berdasarkan pertimbangan pesatnya perkembangan dan kemajuan pembangunan di provinsi Sumatera Selatan umumnya dan khususnya di kabupaten Musi Banyuasin diperkuat oleh aspirasi masyarakat untuk meningkatkan penyelenggaraan pemerintahan, pelaksanaan pembangunan dan pelayanan guna menjamin kesejahteraan masyarakat (Tasmalinda, 2013:63).

Secara administratif kabupaten Banyuasin terdiri dari 19 kecamatan, yaitu: Air Salek, Banyuasin I, Banyuasin II, Banyuasin III, Betung, Makarti Jaya, Muara Padang, Muara Sugihan, Muara Telang, Pulau Rimau, Rambutan, Rantau Bayur, Sembawa, Suak Tapeh, Talang Kelapa, Tanjung Lago, Tungkal llir, Kumbang Padang, Marga Telang (Badan Pusat Statistik, 2012:17).

Pada umumnya kedatangan Islam dan cara menyebarkannya kepada golongan bangsawan dan rakyat umumnya, adalah dengan cara damai, melalui perdagangan dan dakwah oleh mubalig-mubalig atau orang-orang alim. Kemudian apabila situasi politik di kerajaan-kerajaan itu mengalami kekacauan, dan kelemahan disebabkan perebutan kekuasaan di kalangan keluarga raja-raja, agama Islam dijadikan alat politik bagi golongan bangsawan atau raja-raja 
yang menghendaki kekuasaan itu. Mereka berhubugan dengan pedagang-pedagang muslim yang posisi ekonominya kuat karena penguasaan pelayaran di lautan dan perdagangan. Apabila telah terwujud kerajaan Islam, barulah mereka melancarkan perang terhadap kerajaan bukan Islam. Hal ini bukan semata-mata karena masalah agamanya, melainkan karena dorongan politik untuk menguasai kerajaan-kerajaan disekitarnya, misalnya Gowa terhadap kerajaan-kerajaan lainnya di Sulawesi Selatan, Demak, dan Banten terhadap kerajaan Jawa-Hindu (Poesponegoro, 2011:1).

Sejarah kerajaan/kesultanan Palembang terjadi dalam abad ke 17 Masehi dan ke-18 Masehi sampai dengan permulaan abad ke-19 Masehi. Tempatnya adalah di kota Palembang dan sekitarnya, baik di sebelah llir sungai Musi termasuk pulau Bangka dan pulau Belitung maupun di sebelah Ulu sungai Musi dan anak-anak sungainya, yang dikenal dengan nama Batanghari Sembilan. Kota Palembang merupakan Bandar yang keadaannya sangat strategis, karena terletak di kedua tepi sungai Musi yang lebar dan dalam, sehingga dapat dilayari oleh kapal-kapal sampai jauh ke hulu sungai-sungai (Gadjahnata, 1986:67).

Rumusan Masalah: Bagaimanakah jejak Kesultanan Palembang Darussalam di kabupaten Banyuasin?. Tujuan Penelitian: Untuk mengetahui jejak Kesultanan Palembang Darussalam di kabupaten Banyuasin.

\section{B. METODE PENELITIAN}

Berdasarkan rumusan masalah, penelitian ini mendeskripsikan secara rinci tentang jejak Kesultanan Palembang Darussalam di kabupaten Banyuasin. Untuk memahami hal tersebut, dilakukan penelitian secara mendalam dengan menggunakan pendekatan deskriptif kualitatif. Sumber Data. Sumber data dalam penelitian ini adalah: Informan, Dokumen, Tempat penelitian di kabupaten Banyuasin. Teknik Pengumpulan Data: Wawancara Mendalam, Kajian Dokumen, Observasi Langsung di desa Ulak Beriang.

Teknik Cuplikan. Peneliti dalam melakukan kegiatan penelitian ini menggunakan teknik cuplikan purposive sampling pada warga masyarakat yang menyimpan sastra tutur. Validitas Data. Validitas data sangat penting dalam proses pemaparan hasil penelitian, pembahasan dan penarikan simpulan. Dengan adanya validitas data triangulasi yang digunakan: triangulasi data, triangulasi metode.

\section{HASIL DAN PEMBAHASAN \\ 1. Sejarah Kesultanan Palembang Darussalam \\ Kesultanan Palembang Darussalam} adalah suatu kerajaan Islam di Indonesia yang berlokasi di sekitar kota Palembang, Sumatera Selatan sekarang. Kesultanan ini diproklamirkan menjadi kerajaan Islam oleh Sri Susuhunan Abdurrahman, dan dihapuskan keberadaannya oleh pemerintah kolonial Belanda pada 7 Oktober 1823. Menurut riwayat, berdirinya Kesultanan Palembang Darussalam diawali dengan eksistensi Kerajaan Palembang pada abad ke-15. Berdirinya Kerajaan Palembang merupakan dampak atas penaklukan Kerajaan Sriwijaya oleh Majapahit pada tahun 1375 Masehi.

Selepas penaklukan, ternyata Majapahit tidak dapat mengontrol wilayah Sriwijaya dengan baik yang berakibat terjadinya dominasi oleh para saudagar dari Tiongkok di wilayah yang sekarang dikenal dengan nama Palembang itu. Sejarah mengenai Kesultanan Palembang dapat dimulai pada pertengahan abad ke-15 pada masa hidupnya seorang tokoh bernama Ario Dillah atau Ario Damar. Beliau adalah seorang putera dari raja Majapahit yang terakhir, yang mewakili kerajaan Majapahit bergelar Adipati Ario Damar yang berkuasa antara tahun 1455-1486 di Palembang 
Lamo, yang sekarang ini letaknya di kawasan 1 llir.

Pada saat kedatangan Ario Damar ke Palembang, penduduk dan rakyat Palembang sudah banyak yang memeluk agama Islam dan Adipati Ario Damar pun mungkin kemudian memeluk agama Islam, konon namanya berubah menjadi Ario Abdillah atau Ario Dillah. Ario Dillah mendapat hadiah dari Raja Majapahit terakhir Prabu Kertabumi Brawijaya V salah seorang isterinya keturunan Cina yang telah memeluk Islam dan dibuatkan istana untuk Puteri. Pada saat putri ini diboyong ke Palembang ia sedang mengandung, kemudian lahir anaknya yang bernama Raden Fatah. Raden Fatah ini lahir di istana Ario Dillah di kawasan Palembang lama (1 ilir), tempat itu dahulu dinamakan Candi ing Laras, yaitu sekarang terletak di antara PUSRI I dan PUSRI II. Raden Fatah dipelihara dan dididik oleh Ario Dillah menurut agama Islam dan menjadi seorang ulama Islam. Sementara itu hasil perkawinan Ario Dillah dengan putri Cina tersebut, lahir Raden Kusen yaitu adik Raden Fatah namun bapaknya berbeda. Setelah kerajaan Majapahit bubar karena desakan kerajaan-kerajaan Islam, Sunan Ngampel, sebagai wakil Walisongo, mengangkat Raden Fatah menjadi penguasa seluruh Jawa, menggantikan ayahnya.

Pusat kerajaan Jawa dipindahkan ke Demak atas bantuan dari daerah-daerah lainnya yang sudah lepas dari Majapahit seperti Jepara, Tuban, Gresik, Raden Fatah mendirikan kerajaan Islam dengan Demak sebagai pusatnya (kira-kira tahun 1481). Raden Fatah memperoleh gelar Senapati Jimbun Ngabdu'r-Rahman Panembahan Palembang Sayidin Panata'Gama. Setelah Ario Dillah wafat pada tahun 1528 M Kerajaan Demak mengirim anak Pati Unus yaitu Pangeran Sido Ing Lautan sebagai wakil kesultanan Demak, untuk menggantikan Ariodillah. Setelah Pangeran Sido Ing Lautan wafat, ia kemudian diganti oleh anaknya bernama Kiai Gede Ing Sura Tua yang datang dari Demak. Palembang waku itu masih dibawah pengaruh Kesultanan Demak (Hanafiah, 1995:122).

Awal Palembang merdeka dan berdaulat masa Kesultanan Ki Mas Hindi (Endi) karena memproklamasikan putusnya huubngan dengan Mataram pada $1659 \mathrm{M}$. Islam di Palembang baru berkembang secara medalam pada masa pemerintahan Kyai Mas Endi yang juga dikenal dengan Pangeran Ario Kusuma Abdurrahim. Kesultanan Palembang Darussalam secara resmi diproklamirkan oleh Pangeran Ratu Kimas Hindi Sri Susuhunan Abdurrahman Candiwalang Khalifatul Mukminin Sayidul Imam (lebih dikenal Kimas Hindi/Kimas Cinde) sebagai penguasa yang pertama kali menggunakan gelar sultan/sultan pertama (1643-1651 M)/abad 16. Corak pemerintahannya dirubah condong ke arah Melayu dan lebih disesuaikan dengan ajaran Islam (Hanafiah, 1995:175).

\section{Hubungan Iliran dan Uluan}

Konsep lliran dan Uluan secara geografis dapat dibedakan secara keruangan, sehingga keruangan wilayah Sumatera Selatan dibagi menjadi dua, iliran untuk kawasan pusat kota Palembang lama. Uluan adalah seluruh kawasan yang berada di luar kawasan Palembang Lama. Kota Palembang lama meliputi wilayah yang mencakup sebelah Barat adalah kawasan Kuto Gawang (Pusri sekarang) sampai di Timur di kawasan Sri Kecetra/Gandus (Talang Kelapa sekarang). Kawasan lliran sebagai pusat kota identik dengan majunya peradaban, sedangkan kawasan Uluan identik sebagai kawasan penunjang peradaban (Santun, 2010:40-43).

Di dalam sejarah politik Sumatera Selatan pernah berkuasa sebuah kerajaan Buddha yang bernama Sriwijaya, kerajaan Sriwijaya memiliki ruang pengaruh kebudayaan di Thailand, Philipina, Brunai, Semenanjung Melayu dan Indonesia Barat. Palembang menjadi pusat mandala dalam 
lingkar konsentris sejak abad 7 sampai dengan abad $11 \mathrm{M}$. status Palembang sebagai pusat kekuasaan politik diperkuat dengan ditempatkannya prasasti-prasasti penting kerajaan Sriwijaya pada kawasan pusat kota, antara lain Kedukan Bukit, Boom Baru, dan Talang Tuo. Keberadaan prasasti tersebut menunjukkan batas-batas wilayah Palembang tua (Hanafiah, 1995:2-5).

Di luar wilayah inti Palembang terdapat wilayah Uluan yang berada di dalam atau di luar kesatuan politik, seperti marga, sindang, kepungutan, sikap. Kesatuan-kesatuan ruang politik ini turut memainkan peran politik sampai pada masa Kolonial (Hanafiah, 1995:4-5).

\section{Uluan Sebagai Penyangga Kesultanan Darussalam Palembang \\ Dunia Sumatera Selatan memiliki} bentuk bentang alam yang sangat variatif, bentangan hutan berlumpur tebal atau rawarawa yang lebarnya ratusan kilometer hingga ke pedalaman. di hutan rawa gambut mengalir sungai-sungai kecil. Vegetasi bakau dan palem mulai berubah seiring meningkatnya ketinggian tanah berganti dengan tanaman hutan khas tropis. Dataran pesisiran yang berawa biasanya tidak cocok untuk dijadikan kawasan pertanian dan karenanya tidak dapat menjadi sumber penghidupan bagi penduduk. mata pencaharian masyarakat dataran rendah adalah menangkap ikan, mengumpulkan hasil rawa dan laut, serta pemeliharaan pusat-pusat perdagangan daerah yang terdapat di dataran yang lebih tinggi (Andaya, 2016:37-38).

Di daerah pedalaman, sungai memberikan kesuburan bagi tanah. Oleh karena itu daerah Ulu menjadi lebih kondusif sebagai tempat tinggal manusia. Pertanian dengan pola perladangan berpindah dapat dilakukan pada kawasan hutan. Pola pertanian sawah kering lebih dominan dibandingkan sawah basah di pedalaman Sumatera Selatan (Andaya, 2016:39).
Masyarakat Melayu Sumatera Selatan mendiami kawasan pegunungan, perbukitan, dataran, rawa/lebak dan sepanjang garis pantai Timur Sumatera Selatan. Kesatuan pemukiman berawal dari sistem pemukiman puak/kampung/dusun marga dengan ikatan adat dan budaya berdasarkan ikatan kepuyangan (Andaya, 2016:27). Kesatuan permukiman Melayu Sumatera Selatan dibuat di sepanjang bantaran sungai. Penelitian arkeologi yang dilakukan Balai Arkeologi Sumatera Selatan mengungkap sisa-sisa pemukiman kuno masa pra-Sriwijaya ditemukan di kabupaten Musi Banyuasin (Amin, 2016:245).

Sungai/air sangat akrab dengan kebudayaan Melayu. Sejarah Sriwijaya seperti yang tertulis dalam prasasti Kedukan Bukit menerangkan tentang pendirian sebuah wanua di tepi sungai Musi pada tahun 682 Masehi (Wolters, 2011:2). Pada prasasti Telaga Batu dijelaskan tentang upacara meminum air yang telah diberi mantera oleh pendeta suci, sehingga akan membuat peminumnya akan terkena kutukan. Upacara ini berfungsi untuk menjamin kepatuhan bawahan kepada atasan (Wolters, 2011:3).

\section{Jejak Kesultanan Palembang Darussalam Di Banyuasin}

Masyarakat umumnya menyebutkan penduduk asli Banyuasin hampir sama dengan warga Sumatera lainnya. Mereka menjelaskan bahwa orang asli Banyuasin adalah suku Melayu kelompok manusia yang pertama menetap di Banyuasin. Warga mempertegas yang menjadi ciri utama orang Melayu Banyuasin adalah patuh dan setia. Mereka selalu bermusyawarah dan mufakat setiap ada sesuatu yang penting. Falsafah hidupnya beragam Islam dan menggunakan bahasa Melayu. Semuanya ini ada dalam perkembangan sejarah kehidupan masyarakat Banyuasin. Sejalan dengan pendapat itu di kawasan Sumatera memang dikenal adanya etnis Melayu. Mereka apabila ditanya selalu menyataka dirinya 
sebagai keturunan Melayu, orang Melayu, adat Melayu, sopan santun Melayu. Ditegaskan bahwa daerah hunian orang Melayu itu ialah Pesisir Timur Sumatera sampai ke Pesisir Timur Palembang (Rokian, 2014:9).

Sama halnya dengan orang Melayu di Pekan Baru Riau, orang asli Melayu Banyuasin menjunjung tinggi nilai-nilai hukum Islam. Meraka masuk Banyuasin dan menetap melalui sungai Musi di Sungsang menelusuri masuk sebagai pedagang sambil menyebarkan agama Islam dan mengajarkan bahasa Melayu sebagai sarana komunikasi. Sedangkan sungaisungai tersebut adalah sungai Air Banyusin, Air Lalan, Air Upang, Air Tebing, san Air Padang. Disini kehidupan mereka sebagai nelayan kemudian berevolusi jadi petani dan berkebun tanaman tahunan seperti karet.

Menurut tokoh masyarakat Banyuasin asal Pangkalan Balai kelahiran 1934, Muhammad Basri bin Muhammad Amin alias Bas M. Amin, yang pada tahun 1960an menjadi agen terbesar pengadaan sembako dan konveksi di Pangkalan Balai, penduduk Melayu Banyuasin menetap disepanjang pinggiran sungai membuat rumah-rumah yang bertiang pohon-pohon nipah. Asal-usul mereka ini terdiri atas tiga jenis. Pertama, pelarian pasukan kerajaan Sriwijaya (orang Palembang) pasca runtuhnya kejayaan Sriwijaya. Kedua, mereka yang langsung datang dari Malaka pasca jatuh ke Portugis. Ketiga, penduduk asli Banyuasin yang berada disebelah Utara sampai ke Jambi yaitu penduduk asli Banjouasin en Koeboe Strekken (warga Kubu sudah maju) untuk sebutan penduduk asli di zaman kolonial Belanda yang diperkirakan datang melalui daratan sebelum wilayah mereka masuk ke kabupaten Musi Banyuasin. Mereka dari tiga asal-usul penduduk Banyuasin ini hidup beradaptasi dengan lingkungan sungai sebagai bagian penting dari sumber kehidupannya dengan mata pencaharian sebagai nelayan, bertani dan bercocok tanam hingga terus berkembang sejak ratusan tahun silam (Rokian, 2014:10).

Pemerintah kesultanan Palembang Darussalam dalam mengatur daerah yang dutaklukkannya itu kemudian menggunakan aturan dengan sebutan istilah di bawah ini:

Kepungutan adalah wilayah yang awalnya dikunjungi raja atau sultan ketika ke hulu-hulu sungai daerah huluan pada saat untuk pergi pesiar, berburu atau menangkap ikan. Pada saat raja melakukan perundingan bersama tokoh setempat dan dicapai sepakat untuk mengadakan persahabatan dimana daerah tersebut bebas memperdagangkan hasil buminya ke Palembang. Sebagai imbalannya mereka diwajibkan membawa pajak dan sewaktuwaktu diminta siap menyediakan tenaga kerja.

Sindang merupakan daerah perbatasan setiap wilayah Kepungutan yang merupakan wilayah paling ujung atau wilayah pinggir. Penduduknya bertugas menjaga batas-batas kerajaan, mereka dibebaskan dari kewajiban membayar pajak kepada kerajaan. Mereka ini adalah orangorang merdeka wajib melakukan kebiasaan adat seba bagi penduduk asli untuk berkunjung kepada raja setidaknya tiga tahun sekali ke Palembang (keraton) dengan membawa buah tangan.

Sikep adalah sebuah atau sekumpulan dusun yan terletak di daerah pertemuan-pertemuan sungai yang strategis diantara wilayah kepungutan dan sindang. Sikep dianggap sebagai sistem pertahanan wilayah yang alamiah yang menjadi pertahanan rakyat semesta dalam istilah modern sekarang. Penduduknya terdiri dari berbagai etnis, mereka ini dibebaskan dari berbagai macam pungutan pajak karenanya sikep dilepaskan dari sisem marga. Sikep ini di bawah pengawasan dan diperintah langsung oleh pejabat atau pamong dari raja atau sultan yang disebut jenang dan raban.

Jenang dan raban orang-orang kepercayaan raja atau sultan dianggap sebagai pejabat atau pamong yang 
mempunyai tugas-tugas sesuai dengan keahliannya misalnya sebagai tukang kayuh perahu raja atau sultan, tukang kayu, pembawa air atau sebagai prajurit. Tugas yang mereka lakukan disebut dengan gawe rajo (Utomo, 2012:198).

Bayuasin sebagai wilayah kekuasaan kesultanan Palembang Darussalam termasuk kategori daerah sikep. Sama dengan sistem pemerintahan marga daerah di daerah Uluan, wilayah Banyuasun zaman marga kesultanan Palembang Darussalam tidak mempunyai pemerintahan sendiri, tetapi diperintah langsung oleh jenang atau pegawai yang ditunjuk raja Palembang. Jenang dibebaskan dari kewajiban membayar pajak pada umumnya karena mereka adalah kepercayaan raja, tetapi sebagai gantinya wajib bekerja untuk raja (gawe rajo) dengan suatu tujuan tertentu dalam banyak hal kerja seperti berkayuh (mengayuh perahu) atau menjadi penunjuk jalan (perpat).

Contoh wilayah Banyuasin sebagai sikep sejak dahulu adalah dusun Sungsang. Kesultanan mewakilkan Sungsang agar memelihara jalur pelayaran antara Palembang dan Sungsang bebas dari segala rintangan dan halangan pelayaran perahu atau kapal. Dusun lain yang juga sebagai wilayah sikep di Banyuasin adalang Betung yang wajib memelihara sarangsarang burung di muara sungai Abab (Rokian, 2014:16).

Pemerintahan marga di Banyuasin sudah terbentuk sejak zaman kesultanan Palembang Darussalam (1455-1825). Pejabat marga waktu itu disebut oleh sultan Palembang dengan sebutan Rie atau Rijo (bukan kerio). Jabatan Rie ini terus menerus berganti-ganti menurut garis keturunan. Anak Rie yang dianggap cakap, dialah yang menjadi Rie pengganti. Akhirnya sekitar tahun 1850 pada zaman kolonial Belanda, jabatan Rie berganti menjadi Pesirah Kepala Marga. Jika dua periode menjabat kepala marga dengan keberhasilannya, pesirah bisa diangkat Belanda menjadi pangeran seperti pangeran Zainal Abidin di Pangkalan Balai. Pengangkatan pesirah Zainal Abidin oleh residen Belanda yang berkedudukan di Palembang.

Pada zaman pesirah memimpin di Banyuasin, Undang-Undang Simbur Cahaya juga digunakan dalam kehidupan seharihari, demikian pula pasal-pasal dari Undang-Undang ini yang di revisi Belanda juga dirasakan penduduk Banyuasin. Seperti halnya daerah lain, pesirah Banyuasin, saat itu bertanggung jawab kepada kountler, sedangkan kedudukan kountler Banyuasin berada di Talang Betutu Palembang. Saat itu belum ada istilah camat dan belum ada pula sebutan asisten wedena. Ini artinya kehidupan Banyuasin diatur dalam jalur hubungan dengan residen Palembang.

Adanya keterkaitan antara penduduk Banyuasin Lama dan orang-orang kerajaan Sriwijaya pasca dikuasai Majapahit dan kesultanan Palembang Darussalam tertanam di dalam ingatan masyarakat, terdapat cerita rakyat yang berkembang di desa Sako kecamatan Rambutan kabupaten Banyuasin. Awal kisah, setelah kerajaan Majapahit runtuh yang ditaklukan oleh kerajaan Demak pada abad 15 Masehi. Banyak pembesar-pembesar kerajaan Majapahit tersebut beserta keturunnya mengungsi ke pelosok-pelosok tanah air dan salah satu tempat pengungsian pembesar Majapahit tersebut adalah bekas kerajaan Sriwijaya yang juga sebelumnya merupakan daerah kekuasaan kerajaan Majapahit, pada saat itu kadipaten Palembang, pengungsi pembesar Majapahit tersebut sudah berada di bumi Palembang (sekarang). Mereka menyusuri sungai Musi diantaranya adalah nenek moyang Sako yaitu Raden Fatahilah (Lazim disebut raden Ariodilla). Dari sekian lama perjalanan menyusuri sungai Musi akhirnya mereka menghulu ke arah Selatan memasuki sungai Komering (sekarang batanghari Sungai Dua) dan mereka pun memasuki anak sungai Komering yaitu sungai Parung 
(sungai pebatasan Marga Parung Priyayi dan OKI), menghilir kearah Timur dan di ujung sungai Parung inilah nenek moyang Sako bertempat tinggal (7 bersaudara). Di sinilah mereka membuka lahan (ladang untuk bercocok tanaman) dan membuat tempat pemukiman serta menjadi tempat mereka mencari hidup, tempat ini sekarang Tanjung Medu atau Leban Kuning (Kanang, 2010:1-2).

Bertahun-tahun mereka bertempat tinggal, berladang dengan berpola ladang berpindah-pindah, lama kelamaan hampir seluruh dataran tinggi diusahakannya sehingga menjauhi tempat pemukiman asal dan begitulah cara mereka dan akhirnya pindah lagi tempat pemukimannya yaitu sekarang dinamakan Semuruk (Rumah Buruk). Konon ceritanya Raden Ariodilla tidak mempunyai keturunan kecuali para pengikutnya. Demikianlah keseharian hidup nenek moyang kita dari hasil ladangnya mereka jual ke Palembang (masih melalui jalur sungai yaitu berperahu) dan dari hubungan perdagangan inilah nenek moyang Sako banyak menjalin persahabatan dengan orang-orang Kesultanan Palembang, dan ada juga dari anak cucu nenek moyang kita yang menikah dengan keturunan Kesultanan Palembang. Jadi bercampurlah keturunan nenek moyang kita dengan darah Palembang itulah dikatakan keturunan nenek moyang Sako Japal (Jawa-Palembang). Itulah dari segi bahasa terdapat campuran bahasa antara bahasa Jawa dan bahasa Palembang. Bahasa Jawa diantaranya ending pundit, kulo nuhun, buri (belakang) dan lain-lain. Bahasa Palembang yaitu seperti panggilan kepada anak laki-laki nak Agus. Agama yang dianut nenek moyang Sako pertama yaitu agama Hindu sesuai dengan pada masa itu kerajaan Majapahit menganut agama Hindu setelah bergaul dengan orang-orang Kesultanan Palembang Darusalam maka berubalah agama yang dianut yaitu menjadi Islam (Kanang, 2010:12).
Tradisi kuno di desa ini menceritakan bahwa para leluhur melakukan upacara rajah dilengkapi dengan sesajian hewan, tumbuh-tumbuhan, dan makanan tradisional sepanjang 500 meter. Fungsi dari pada upacara rajah adalah untuk menangkal mara bahaya, musibah, dan pralaya berupa serangan binatang buas dan hewan melata, serangan dari musuh berupa peperangan antar suku dan antar desa, kebakaran, banjir, pertengkaran, pembunuhan, dan tindak kejahatan lainnya. Tradisi ini masih bertahan walaupun dalam bentuk disederhanakan dan di Islamkan yang sekarang dikenal dengan nama sedekah dusun desa Sako. Pada zaman sekarang sedekah dusun dilaksanakan satu tahun sekali yaitu pada saat hari raya.

\section{SIMPULAN}

Sistem marga sudah sejak lama berkembang saat kerajaan Sriwijaya atau sebelum kesultanan Palembang Darussalam ada. Selain itu daerah Uluan tidak ditundukkan dengan kekerasan karena raja Palembang tidak mempunyai tentara yang teratur saat itu.

Bayuasin sebagai wilayah kekuasaan kesultanan Palembang Darussalam termasuk kategori daerah sikep. Sama dengan sistem pemerintahan marga daerah di daerah Uluan, wilayah Banyuasun zaman marga kesultanan Palembang Darussalam tidak mempunyai pemerintahan sendiri, tetapi diperintah langsung oleh jenang atau pegawai yang ditunjuk raja Palembang.

\section{DAFTAR PUSTAKA}

Amin, Jusna. J. A, dkk. 2016. Mengenal Arsitektur Lanskap Nusantara. Yogyakarta: Pustaka Pelajar.

Andaya, Barbara Watson. 2016. Hidup Bersaudara. Sumatera Tenggara Pada Abad XVII dan XVIII. Yogyakarta: Ombak.

Badan Pusat Statistik dan BAPPEDA Kabupaten Banyuasin. 2012. 
Banyuasin dalam Angka: Banyuasin in Figures 2012. Banyuasin: Badan Pusat Statistik dan BAPPEDA Kabupaten Banyuasin.

Gadjahnata dan Sri Edi Swasono. 1986. Masuk dan Berkembangnya Islam di Sumatera Selatan. Jakarta: Universitas Indonesia Press.

Hanafiah, Djohan. 1995. Melayu-Jawa: Citra Budaya dan Sejarah Palembang. Jakarta: Raja Grafindo Persada.

Kanang, Suadi, 2015. Profil Desa Sako Kecamatan Rambutan Kabupaten Banyuasin. Banyuasin. Pemerintah Desa Sako Kecamatan Rambutan Kabupaten Banyuasin.

Poesponegoro, Marwati Djoened dan Nugroho Notosusanto. 2011. Sejarah Nasional Indonesia IV. Jakarta: Balai Pustaka.

Rangkuti, Nurhadi. 2007. Tabir Pedaban Sungai Lematang. Palembang: Balai Arkeologi Palembang.

Rokian, Ajmal. 2014. Sejarah, Khasanah Budaya dan Profil Potensi Kabupaten Banyuasin. Banyuasin: Dinas Pariwisata, Seni, Budaya, Pemuda dan Olahraga Kabupaten Banyuasin, Sumatera Selatan.

Santun, Dedi Irwanto Muhammad, dkk. 2016. Iliran dan Uluan Dikotomi dan Dinamika dalam Sejarah Kultural Palembang. Yogyakarta: Eja Publisher.

Tasmalinda dan Parliza Hendrawan. 2013. Jejak Langkah Amirudin Inoed: 10 Tahun Memimpin Banyuasin. Lampung: Indepth Publishing.

Utomo, Bambang Budi, dkk. 2012. Kota Palembang, dari Wanua Sriwijaya Menuju Palembang Modern. Palembang: Raja Grafindo Persada.

Wolters, O.W. 2011. Kemaharajaan Maritim Sriwijaya dan Perniagaan Dunia Abad III-Abad VII. Depok: Komunitas Bambu. 